\title{
THE PROTEINS OF BOVINE SPERMATOZOA FROM THE CAPUT AND CAUDA EPIDIDYMIDIS*
}

\author{
U. LAVON, $\dagger$ R. VOLGANI AND D. DANON $\ddagger$ \\ Department of Animal Science, Volcani Institute of Agricultural Research, Rehovot, Israel, \\ and $\ddagger$ The Weizmann Institute of Science, Rehovot, Israel
}

(Received 31st March 1970)

Summary. Changes occurring in the proteins of bovine spermatozoa during their migration from the caput to the cauda epididymidis were studied.

The percentage of total nitrogen in the dry matter was greater in the cauda than in the caput spermatozoa, but the nitrogen content $/ 10^{9}$ cells was less in the cauda spermatozoa. The amount of DNA for the same number of cells remained constant during this stage of maturation. The decrease in the nitrogen content indicated a loss of protein during maturation of bovine spermatozoa in the epididymis. Amino acid analysis of the dry matter of the sperm cells showed an increase in the percentage of arginine and cystine and a decrease in the percentage of glutamic and aspartic acids, alanine, methionine, isoleucine and leucine during passage of spermatozoa through the epididymis. Lipoprotein content decreased during the maturation of the sperm cells, and a slight increase occurred in several of the other proteins. Amino acid analysis of the extracted proteins showed differences in the percentage of several amino acids between caput and cauda spermatozoa in the $F_{1}$ and $F_{2}$ fractions. Gel disc electrophoresis of the various caput and cauda sperm proteins indicated a different number of bands and a different colour intensity for those fractions in which a different amino acid composition was found.

The results suggest that the lipoproteins of the cell membrane may be the site of alterations in the quantity, composition and electrophoretic behaviour of the proteins of bovine spermatozoa during their maturation.

\section{INTRODUCTION}

Several publications report on the protein content and amino acid composition of the spermatozoa of different species; details are given by Mann (1964) and in the studies of Bril-Petersen \& Westenbrinik (1963), Hunter \& Hafs (1964),

\footnotetext{
* Contribution from the Volcani Institute of Agricultural Research, Rehovot, Israel. 1969 Series, No. 1638-E.

$\dagger$ Present address: The Animal Research Station, 307 Huntingdon Road, Cambridge.
} 
Henricks \& Mayer (1965a, b), Gledhill, Gledhill, Rigler \& Ringertz (1966) and Ingles, Trevithick, Smith \& Dixon (1966). A few of them are concerned with the changes associated with the alteration in the basic proteins of the nucleus from second spermatocyte or round spermatid to the spermatozoon (Alfert, 1956; Vendrely, Knobloch \& Vendrely, 1957; Gledhill et al., 1966; Ingles et al., 1966). Two reports deal with the changes in the proteins during sperm passage through the epididymis. Berry \& Mayer (1960) reported an increase in the percentage of the basic amino acids and a decrease in that of the acidic acids of the basic proteins. Gledhill et al. (1966) assumed that there is only a small increase in the percentage of basic amino acids in the basic proteins of the nucleus following the sperm passage through the genital tract.

Several methods of sperm protein extraction are reported in the literature. Those adopted for fish spermatozoa generally use water or salt solutions and are described by Felix (1960), while, for mammalian spermatozoa, a stronger treatment is needed for the disruption of the cell membrane. Hence, the use of glass beads, enzymes or reducing agents was adopted (Green, 1940; Zittle \& O'Dell, 1941; Berry \& Mayer, 1959; Bhargava, Bishop \& Work, 1959a; BrilPetersen \& Westenbrinik, 1963; Hunter \& Hafs, 1964; Henricks \& Mayer, $1965 \mathrm{a}, \mathrm{b})$. As most of the studies have dealt with the basic proteins, it was necessary to find appropriate treatments which would facilitate the extraction of both the lipoproteins and the basic proteins in sequence.

The purpose of the present investigation was to determine the amount and composition of total proteins in the dry matter, to extract various proteins by chemical methods, to determine their quantity and composition, and to characterize them by gel disc electrophoresis, in order to compare the findings for spermatozoa derived from the caput and cauda epididymidis. This study included the following determinations: (a) total nitrogen, (b) desoxyribonucleic acid (DNA), (c) amino acid composition of the dry matter, (d) extraction of proteins from the dry matter, (e) the protein content in each fraction, (f) amino acid composition of the extracted proteins, and (g) gel disc electrophoresis of these proteins.

\section{METHODS}

\section{Sperm collection}

Spermatozoa from the caput and cauda epididymidis were obtained from seven 14- to 16-month-old bulls immediately after slaughter (Grogan, Mayer \& Sikes, 1966). The cells were separated from fluids and remnants of tissue as described by Lavon, Volcani \& Danon (1968). The cells were resuspended in a known volume of $0.9 \% \mathrm{NaCl}$ solution in order to facilitate the estimation of their number.

\section{Sperm counting}

The number of spermatozoa in a given collection was counted in duplicate samples using an EEL colorimeter and a haemocytometer (four counts on each sample). 
Dry matter determination

This procedure was carried out as described by Lavon et al. (1968). Calculation of dry matter content was made in terms of percentage of the fresh weight and of $\mathrm{mg} / 10^{9}$ cells.

\section{Nitrogen determination}

Total nitrogen was determined on 10-mg samples of the lyophilized dry matter by the micro-Kjeldahl method; the nitrogen was determined with a Technicon AutoAnalyzer according to the method of Clare \& Stevenson (1964).

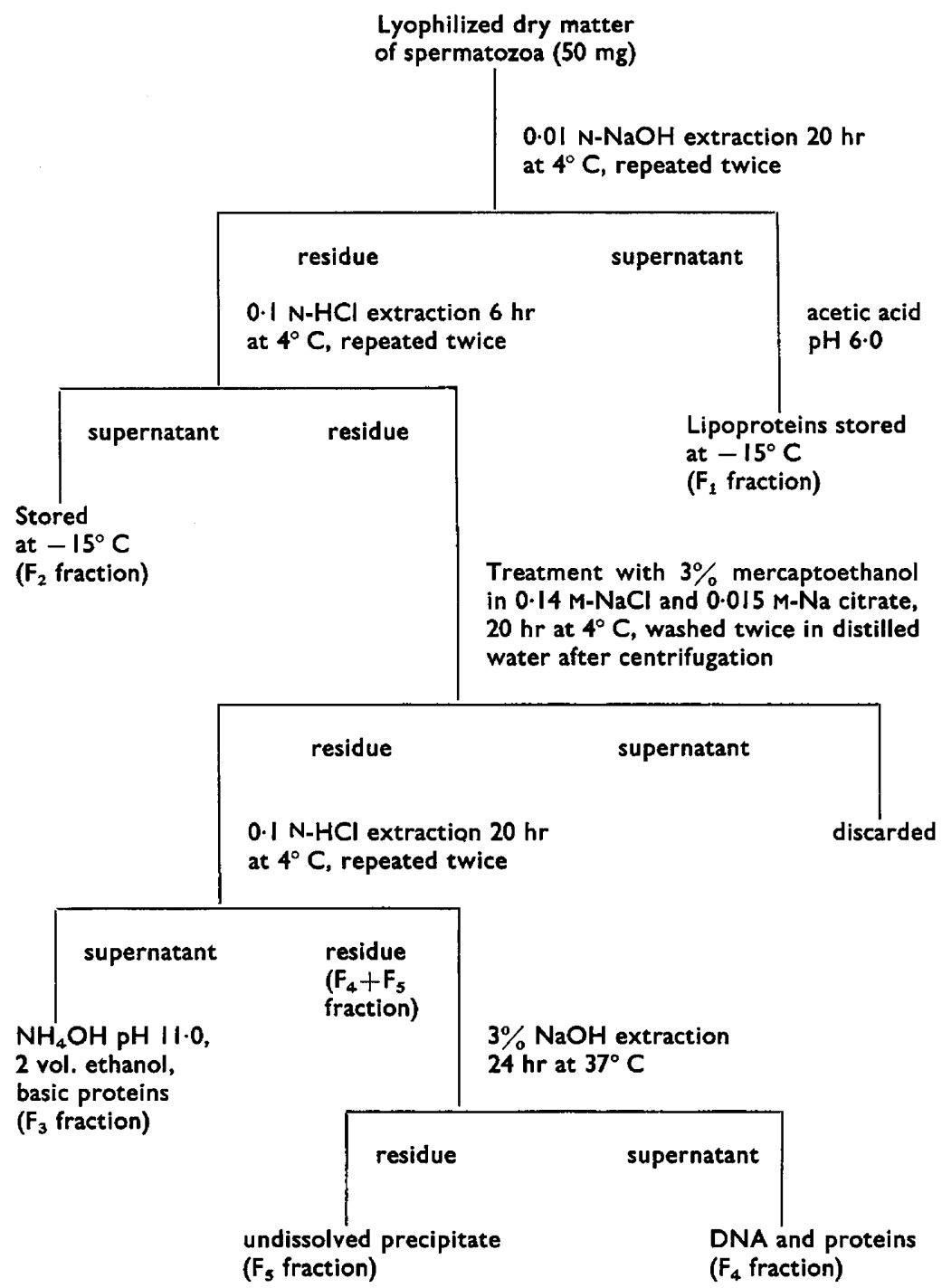

FlOW SheEt. A fractionation scheme for the isolation of sperm proteins from the caput and cauda epididymidis. 
Determination of $D \mathcal{N} A$

This was carried out on the same samples for which the total nitrogen was determined. The DNA was extracted from the cells according to Summerhill $\&$ Olds (1961) and was determined by its phosphorous content (9.89\%) according to the method of Fiske \& Subbarow (1925) in a Technicon AutoAnalyzer.

\section{Amino acid analysis}

This was carried out on 3-mg samples of the lyophilized dry matter of spermatozoa from the caput and cauda epididymidis of each of six bulls, using a Beckman 120B amino acid analyser. The analyses of the extracted proteins were performed on samples of 500 to $1000 \mu \mathrm{g}$ of protein from the various fractions. The samples were hydrolysed in $6 \mathrm{~N}-\mathrm{HCl}$ for $24 \mathrm{hr}$ in evacuated sealed glass ampoules at $110^{\circ} \mathrm{C}$ before analysis.

\section{Protein extraction}

Sperm dry weight samples were treated with $0.1 \mathrm{~N}-\mathrm{NaOH}, 1 \% \mathrm{NaCl}$ or $0.1 \mathrm{~N}-\mathrm{HCl}$. The protein content of each extract was determined in an Elmer Perkins Hitachi Spectrophotometer at $280 \mathrm{~m} \mu$. Different sequences of treatments were tried and the scheme shown in the Flow Sheet was adopted. This scheme is based on the work of Berry \& Mayer (1959), Henricks \& Mayer (1965b) and Summerhill \& Olds (1961).

The treatment with mercaptoethanol was incorporated as proposed by Green (1940) and by Henricks \& Mayer (1965b) in order to disrupt the S-S linkages of the cell membrane, and in order to facilitate the extraction of the keratin-like basic proteins by $0 \cdot 1 \mathrm{~N}-\mathrm{HCl}$ solution. The extractable material in each fraction was calculated by subtraction of the residual material remaining after treatment, from that present before treatment.

\section{Determination of total protein in the extracts}

The protein content in each fraction obtained by using the above-mentioned sequence was determined according to Lowry, Rosebrough, Farr \& Randall (1951) using a standard of bovine serum albumin as reference.

\section{Electrophoresis}

Gel disc electrophoresis was performed at both acidic and basic $\mathrm{pH}$ by the methods of Reisfeld, Lewis \& Williams (1962) and Davis (1964), respectively. The quantity of protein in each gel was about 200 to $300 \mu \mathrm{g}$. The length of the acrylamide gels and the time of electrophoresis were changed according to the extract that was separated and to the $\mathrm{pH}$ used for the run. A modification was also adopted in which the staining of the gels with Coomassie Brilliant Blue (ICI R250) was carried out with diluted dye solution (0.01\%) in TGA $12.5 \%$ trichloroacetic acid (TCA) for $18 \mathrm{hr}$. The removal of the surplus dye was achieved by repeated washings with $12.5 \%$ TGA.

\section{Statistical analysis}

The results for each of the parameters were analysed according to Snedecor (1948) by a two-way analysis of variance (different locations in the epididymis 
and different bulls). The standard error (S.E.) of the means for the caput and the cauda and the least significant difference (L.S.D.) at the $5 \%$ level were given when significant differences were found.

\section{RESULTS}

\section{Total nitrogen}

Seven determinations showed an increase in the $\%$ total nitrogen in the dry matter $(10 \mathrm{mg}$ ) from $11.08 \pm 0.11$ in the caput to $12 \cdot 30 \pm 0.11$ in the cauda epididymidis (L.S.D. $5 \%=0 \cdot 39$ ). However, when the results were related to the number of sperm cells from which the $10-\mathrm{mg}$ samples were taken, a decrease from $3.41 \pm 0.08 \mathrm{mg} / 10^{9}$ cells in the caput to $3.11 \pm 0.08 \mathrm{mg} / 10^{9}$ cells in the cauda epididymidis was found (L.S.D. $5 \%=0.27$ ).

\section{$D \mathcal{N} A$ content}

The values obtained from five determinations, based on the phosphorous content, were $2.90 \mathrm{mg} / 10^{9}$ cells for the caput and $3.03 \mathrm{mg} / 10^{9}$ cells for the cauda epididymidis; the difference was not significant. These values are in agreement with those reported by other investigators (Mann, 1964, p. 147). Using a value of $15 \%$ nitrogen in the DNA (an average value of results quoted by Mann, 1964, Ghapter VI), it can be calculated that the net protein nitrogen is $2.98 \mathrm{mg} / 10^{9}$ cells in the caput and $2.66 \mathrm{mg} / 10^{9}$ cells in the cauda epididymidis. This difference is equal to a decrease of $2.0 \mathrm{mg}$ of protein in the dry weight of $10^{9}$ spermatozoa during their migration from the caput to cauda epididymidis.

\section{Amino acid composition of the dry matter}

The amino acid composition of the proteins present in the dry matter of spermatozoa from the caput and cauda epididymidis is given in Table 1. It can be seen from this Table that a significant decrease in the acidic and neutral acids, and a parallel increase in the basic amino acids occur during sperm passage from caput to cauda epididymidis. The decrease in the acidic acids was manifested in both the glutamic and aspartic acids. In the neutral acids, there was a decrease in alanine, methionine, isoleucine and leucine, an increase in cystine, and no change in the others. The increase in arginine was $3.73 \%$, while the percentage of lysine and histidine was not altered.

\section{Protein extraction}

The extractions with various agents showed a higher protein content in the dry matter of spermatozoa from the caput than the cauda epididymidis for all the chemical treatments. The results are presented in Table 2.

From these results, it was not clear whether the different agents extracted the same proteins, and if so, to what extent they achieved this. Therefore, the particular sequence of treatments, the results of which are given in Table 3 , was employed.

The percentage dry matter extracted by $0 \cdot 1 \mathrm{~N}-\mathrm{NaOH}$ was 64 in the caput and 50 in the cauda epididymidis. The decrease of the extractable material from caput to cauda in this fraction occurred both in the proteins and in the 
non-protein compounds (lipids, carbohydrates, etc.). This decrease was more significant when the values were expressed as $\mathrm{mg} / 10^{9}$ cells rather than as percentage dry matter. Mayer, Madera-Orsini \& Berry (1957), who employed the same initial treatment, identified the extracted proteins, by precipitation with acetic acid at $\mathrm{pH} 6.0$ and by chemical analysis, to be mainly lipoproteins.

\section{TABLE 1}

AMINO ACID COMPOSITION OF THE PROTEINS OF SPERMATOZOA COLLEGTED FROM THE GAPUT AND CAUDA EPIDIDYMIDIS OF SIX BULLS

\begin{tabular}{|c|c|c|c|c|}
\hline Amino acid & $\begin{array}{c}\text { Mean for } \\
\text { caput }^{*}\end{array}$ & $\begin{array}{c}\text { Mean for } \\
\text { cauda }\end{array}$ & $\begin{array}{l}\text { S.E. of } \\
\text { means }\end{array}$ & L.S.D. $5 \%$ \\
\hline $\begin{array}{l}\text { Lysine } \\
\text { Histidine } \\
\text { Arginine } \\
\text { Aspartic acid } \\
\text { Threonine } \\
\text { Serine } \\
\text { Glutamic acid } \\
\text { Proline } \\
\text { Glycine } \\
\text { Alanine } \\
\text { Half cystine } \\
\text { Valine } \\
\text { Methionine } \\
\text { Isoleucine } \\
\text { Leucine } \\
\text { Tyrosine } \\
\text { Phenylalanine }\end{array}$ & $\begin{array}{r}6 \cdot 65 \\
2 \cdot 46 \\
15 \cdot 79 \\
8 \cdot 10 \\
4 \cdot 52 \\
4 \cdot 93 \\
12 \cdot 93 \\
5 \cdot 11 \\
4 \cdot 40 \\
4 \cdot 10 \\
3 \cdot 08 \\
5 \cdot 13 \\
2 \cdot 29 \\
3 \cdot 90 \\
8 \cdot 01 \\
4 \cdot 32 \\
4 \cdot 17\end{array}$ & $\begin{array}{r}6 \cdot 37 \\
2 \cdot 61 \\
19 \cdot 52 \\
7 \cdot 33 \\
4 \cdot 49 \\
4 \cdot 85 \\
11 \cdot 62 \\
4 \cdot 92 \\
4 \cdot 22 \\
3 \cdot 71 \\
4 \cdot 19 \\
4 \cdot 94 \\
2 \cdot 05 \\
3 \cdot 64 \\
7 \cdot 49 \\
4 \cdot 08 \\
3.97\end{array}$ & $\begin{array}{c}\text { NS } \\
\text { NS } \\
\pm 0.42 \\
\pm 0 \cdot 18 \\
\text { NS } \\
\text { NS } \\
\pm 0 \cdot 19 \\
\text { NS } \\
\text { NS } \\
\pm 0.05 \\
\pm 0.17 \\
\text { NS } \\
\pm 0.05 \\
\pm 0.07 \\
\pm 0.08 \\
\text { NS } \\
\text { NS }\end{array}$ & $\begin{array}{l}\overline{-} \\
1.52 \\
0.64 \\
\overline{-} \\
0.69 \\
\overline{-} \\
0 \cdot 18 \\
0.62 \\
\overline{0.18} \\
0.25 \\
0.29 \\
\overline{-}\end{array}$ \\
\hline $\begin{array}{l}\text { Total basic acids } \\
\text { Total acidic acids } \\
\text { Total neutral acids }\end{array}$ & $\begin{array}{l}24.90 \\
21.03 \\
54.07\end{array}$ & $\begin{array}{l}28 \cdot 49 \\
19 \cdot 24 \\
52 \cdot 27\end{array}$ & $\begin{array}{l} \pm 0.57 \\
\pm 0.21 \\
\pm 0.42\end{array}$ & $\begin{array}{l}2.06 \\
0.77 \\
1.52\end{array}$ \\
\hline
\end{tabular}

* The amino acid content is expressed as a percentage of the protein. NS $=$ Not significant.

TABLE 2

PERGENTAGE OF PROTEINS IN THE DRY MATTER OF SPERMATOZOA FROM THE CAPUT AND CAUDA EPIDIDYMIDIS OF FOUR BULLS TREATED WITH VARIOUS AGENTS

\begin{tabular}{l|c|c|c|c}
\hline \multicolumn{1}{c|}{ Treatment } & Caput & Cauda & $\begin{array}{c}\text { S.E. of } \\
\text { means }\end{array}$ & L.S.D. 5\% \\
\hline $0.1 \mathrm{~N}-\mathrm{NaOH}$ & 35.0 & 26.2 & \pm 0.38 & 1.72 \\
$1 \% \mathrm{NaCl}$ & 28.9 & 20.7 & \pm 1.82 & $8 \cdot 11$ \\
$0.1 \mathrm{~N}-\mathrm{HCl}$ & 20.7 & 14.5 & \pm 1.23 & 5.50 \\
\hline
\end{tabular}

Following the treatment with $0 \cdot 1 \mathrm{~N}-\mathrm{HCl}$ (Fraction $\mathrm{F}_{2}$ ), the percentage of extractable material increased from caput to cauda. The mercaptoethanol facilitated the extraction of 4 to $6 \%$ of the dry matter $\left(\right.$ Fraction $\left.\mathrm{F}_{3}\right)$. This finding is considerably lower than that of Henricks \& Mayer (1965b) who obtained 12 to $15 \%$ basic proteins for ejaculated boar sperm cells. The remaining material was found to contain all the DNA (as no traces of it were identified in Fraction 
$\mathrm{F}_{1}, \mathrm{~F}_{2}$ and $\mathrm{F}_{3}$ ) and residual proteins, most of them basic in character. The $3 \% \mathrm{NaOH}$ extracted 20 to $30 \%$ of the dry matter (Fraction $\mathrm{F}_{4}$ ), whereas the undissolved precipitate (Fraction $\mathrm{F}_{5}$ ) comprises 5 to $8 \%$ of it. When the results were given as percentage dry matter, an increase in the extractable material and occasionally in the proteins or in the non-protein material from caput to cauda, was found in the $F_{2}, F_{3}, F_{4}$ and $F_{4}+F_{5}$ fractions. This increase was partly cancelled when the data were expressed as $\mathrm{mg} / 10^{9}$ cells. In this case, the differences were significant only for the extractable material in Fraction $F_{2}$ and for the basic proteins of Fraction $F_{3}$.

TABLE 3

THE TOTAL MATERIAL, PROTEINS AND NON-PROTEINS EXTRACTED FROM THE DRY MATTER OF SPERMATOZOA FROM THE GAPUT AND CAUDA EPIDIDYMIDIS OF SIX BULLS, USING THE SEQUENGE OF TREATMENTS DESGRIBED IN THE FLOW SHEET

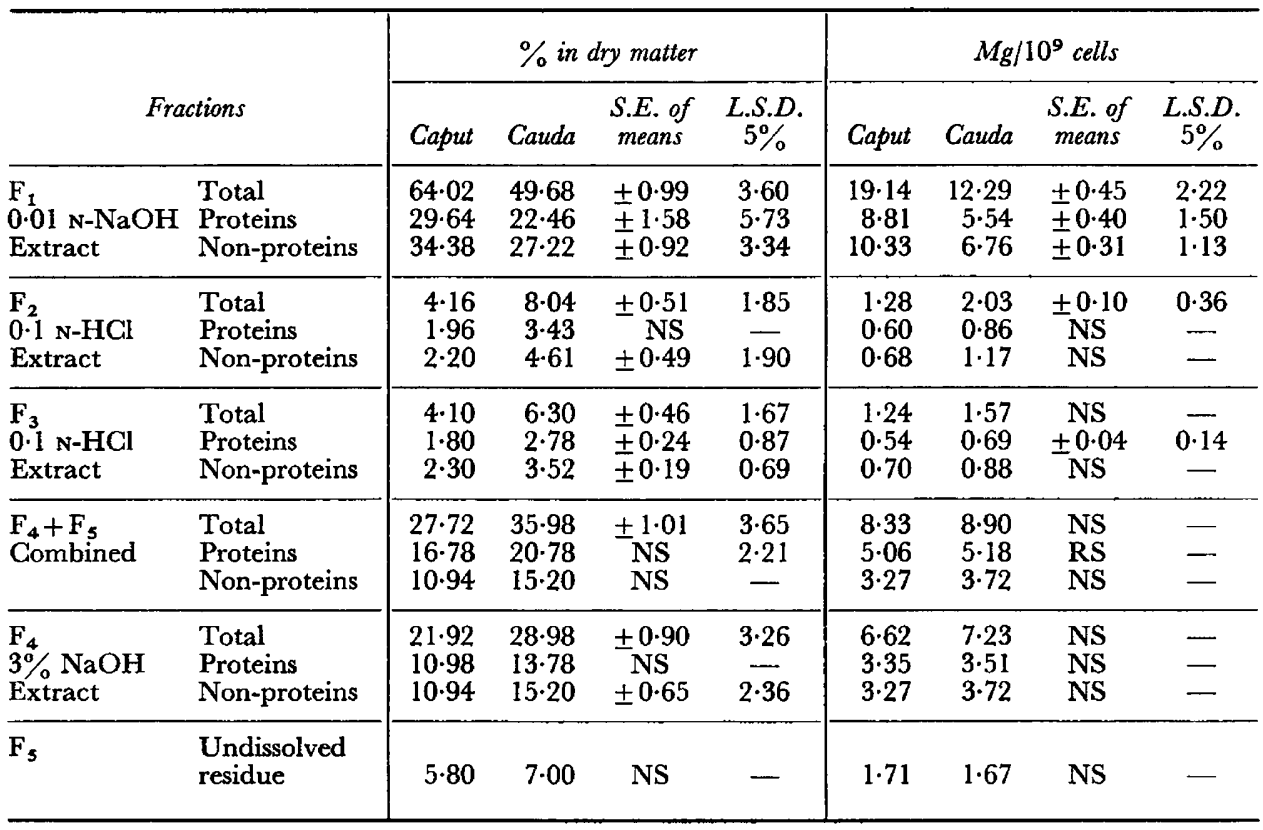

The components are expressed as a percentage of the dry matter and as $\mathrm{mg} / 10^{9}$ cells.

NS $=$ Not significant.

Amino acid composition of the extracted proteins

The data for the various fractions are given in Table 4.

The data of the amino acid composition of both caput and cauda cells show a wide variation in the composition of the proteins of the various fractions. Several points have to be emphasized: (a) In general, significant differences were observed in the amino acid composition between caput and cauda cells for histidine and alanine in Fraction $F_{1}$ and arginine, serine and methionine in Fraction $F_{2}$. Differences were also noted in Fractions $F_{4}$ and $F_{5}$, although these were not significant. (b) Fraction $F_{1}$ was rich in aspartic and glutamic acids, lysine and leucine and very poor in arginine and cystine. (c) The content of 
arginine and cystine was higher, and that of the acidic acids, lysine and some of the neutral acids, lower, in the $F_{2}$ than in the $F_{1}$ fraction. (d) In Fraction $\mathrm{F}_{3}$, arginine was the major amino acid and comprised almost $50 \%$ of the total acids. Cystine and tyrosine were also present in relatively high proportions, whereas the other acids contributed only a small percentage. (e) The combined residue $F_{4}+F_{5}$ was less basic than the $F_{3}$ fraction, but contained a high percentage of arginine and cystine. (f) Fraction $\mathrm{F}_{4}$ showed a percentage of basic amino acids similar to that in the $\mathrm{F}_{4}+\mathrm{F}_{5}$ residue, though there appeared to be a decrease in the lysine and an increase in the arginine content from caput to

TABLE 4

THE AMINO ACID COMPOSITION OF THE EXTRACTED PROTEIN FRACTIONS FROM THE DRY MATTER OF SPERMATOZOA FROM THE GAPUT AND CAUDA EPIDIDYMIDIS

\begin{tabular}{|c|c|c|c|c|c|c|c|c|c|c|c|c|}
\hline \multirow[b]{2}{*}{ Amino acid } & \multicolumn{2}{|c|}{$F_{1}$} & \multicolumn{2}{|c|}{$F_{2}$} & \multicolumn{2}{|c|}{$F_{3}$} & \multicolumn{2}{|c|}{$F_{4}+F_{5}$} & \multicolumn{2}{|c|}{$F_{4}$} & \multicolumn{2}{|c|}{$F_{5}$} \\
\hline & Caput & Cauda & Caput & Cauda & Caput & Cauda & Caput & Cauda & Caput & Cauda & Caput & Cauda \\
\hline Lysine & $10 \cdot 34$ & $9 \cdot 28$ & $8 \cdot 51$ & $8 \cdot 51$ & $2 \cdot 83$ & $3 \cdot 17$ & $5 \cdot 16$ & 5.09 & $5 \cdot 70$ & $4 \cdot 79$ & $3 \cdot 75$ & 3.88 \\
\hline Hist & $2 \cdot 22$ & $2.54 *$ & 3.00 & $3 \cdot 14$ & 2.75 & $2 \cdot 89$ & 2.31 & $2 \cdot 38$ & $2 \cdot 35$ & $2 \cdot 28$ & 1.81 & $\begin{array}{l}1.89 \\
-19\end{array}$ \\
\hline Arginine & $4-59$ & $5 \cdot 22$ & 9.45 & $7.82 \dagger$ & $49 \cdot 80$ & $49 \cdot 17$ & 26.96 & 27.48 & $28 \cdot 50$ & 32.08 & 41.69 & $38 \cdot 11$ \\
\hline Aspartic acid & $10 \cdot 20$ & $10 \cdot 34$ & 9.29 & $9 \cdot 25$ & $2 \cdot 51$ & 2.73 & $6 \cdot 22$ & $5 \cdot 26$ & 6.06 & $5 \cdot 30$ & 4.60 & 5.06 \\
\hline Threonine & $5 \cdot 07$ & $5 \cdot 24$ & $4 \cdot 71$ & $4 \cdot 82$ & $4 \cdot 16$ & $4 \cdot 20$ & 4.06 & $4 \cdot 05$ & 3.55 & 3.54 & 3.63 & $3 \cdot 69$ \\
\hline Serine & $5 \cdot 00$ & 5.42 & $5 \cdot 10$ & $5 \cdot 42 \pi$ & $2 \cdot 81$ & 3.51 & $4 \cdot 48$ & $4 \cdot 38$ & 3.84 & 3.70 & 3.37 & $3 \cdot 48$ \\
\hline Glutamic acid & $15 \cdot 66$ & 15.89 & 14.60 & $14 \cdot 18$ & 6.01 & $6 \cdot 17$ & 8.56 & 8.27 & 9.91 & 8.51 & 6.86 & $7 \cdot 17$ \\
\hline Proline & $5 \cdot 66$ & $5 \cdot 72$ & $5 \cdot 87$ & 6.46 & $1 \cdot 64$ & $2 \cdot 06$ & $4 \cdot 47$ & 4.88 & 4.05 & 4.67 & 3.22 & 4.04 \\
\hline Clycin & 4.44 & $4 \cdot 28$ & 4.09 & 3.79 & 2.44 & $2 \cdot 45$ & 4.86 & 5.05 & 6.92 & $7 \cdot 47$ & 2.94 & $3 \cdot 22$ \\
\hline Alanine & $5 \cdot 15$ & $4.78 \$$ & 4.49 & 4.59 & 1.96 & 2.09 & 2.95 & $3 \cdot 11$ & $2 \cdot 98$ & $2 \cdot 92$ & $2 \cdot 81$ & 2.97 \\
\hline Half cystine & 1.29 & 1.65 & 1.94 & $2 \cdot 10$ & 3.78 & $3 \cdot 15$ & 4.27 & 4.07 & 1.02 & 1.06 & 1.09 & 0.92 \\
\hline Valine & $6 \cdot 33$ & $6 \cdot 18$ & 5.57 & $5 \cdot 56$ & $3 \cdot 65$ & $3 \cdot 46$ & 4.63 & $4 \cdot 60$ & 4.53 & $4 \cdot 37$ & 3.43 & 3.94 \\
\hline Methionine & $2 \cdot 46$ & $2 \cdot 30$ & 1.75 & $2 \cdot 46 \ddagger$ & 0.97 & $1 \cdot 14$ & 1.93 & 1.82 & 1.54 & $1 \cdot 42$ & 1.44 & 1.57 \\
\hline Isoleucine & 4.80 & 4.70 & 4.64 & 4.92 & $2 \cdot 29$ & $2 \cdot 24$ & $3 \cdot 40$ & 3.31 & 2.98 & $2 \cdot 81$ & $2 \cdot 74$ & $2 \cdot 86$ \\
\hline Leucine & $9 \cdot 21$ & $9 \cdot 14$ & 8.28 & 8.47 & 4.29 & 4.56 & $7 \cdot 21$ & $7 \cdot 10$ & $7 \cdot 17$ & $6 \cdot 35$ & $7 \cdot 27$ & $7 \cdot 26$ \\
\hline Tyrosine & $3 \cdot 34$ & 3.00 & $4 \cdot 22$ & $4 \cdot 27$ & $5 \cdot 33$ & $4 \cdot 37$ & 4.79 & 4.85 & 5.59 & $5 \cdot 73$ & 3.95 & 4.41 \\
\hline Phenylalanine & 4.24 & 4.06 & 4.50 & 4.27 & $2 \cdot 78$ & 2.65 & 3.77 & 3.63 & 3.34 & $3 \cdot 05$ & $5 \cdot 44$ & $5 \cdot 54$ \\
\hline
\end{tabular}

$*$ S.E. $= \pm 0.02$, L.S.D. $5 \%=0 \cdot 12$, †S.E. $= \pm 0 \cdot 24$, L.S.D. $5 \%=1 \cdot 46, \ddagger$ S.E. $= \pm 0 \cdot 11$, L.S.D. $5 \%$ $=0.67, \S S . \bar{E} .= \pm 0.04$, L.S.D. $5 \%=0.24, \uparrow S . E .= \pm 0.05$, L.S.D. $5 \%=0.30$

The quantity of each amino acid is expressed as a percentage of the protein. The values in Fractions $\mathrm{F}_{1}, \mathrm{~F}_{2}$ and $\mathrm{F}_{3}$ are derived from three bulls and in Fractions $F_{4}+F_{5}, \mathrm{~F}_{4}$ and $\mathrm{F}_{5}$ from two bulls.

cauda. The slight decrease in the acidic acids from caput to cauda, which was greater in Fraction $F_{4}$ than in the $F_{4}+F_{5}$ residue, was not significant. The same was noted also for leucine. Minor changes from the $F_{4}+F_{5}$ fraction were found for most of the acids, of which the high value for glycine and the very low one for cystine should be emphasized. $(\mathrm{g})$ Fraction $\mathrm{F}_{5}$ included basic proteins which contained about $40 \%$ arginine. The percentage of cystine, however, was very low $(1 \%)$ contrary to what would have been expected from the results of the $\mathrm{F}_{4}+\mathrm{F}_{5}$ and the $\mathrm{F}_{4}$ fractions.

\section{Gel disc electrophoresis}

The results of the electrophoretic separations are shown in Text-figs. 1 to 4 for the four fractions $\left(F_{1}\right.$ to $\left.F_{4}\right)$ which were obtained from the spermatozoa of the caput and the cauda epididymidis. 
It can be seen that following the separation of the proteins of Fractions $\mathbf{F}_{1}$, $F_{2}$ and $F_{4}$ by gel disc electrophoresis, differences in the number of bands between sperm cells from the caput and cauda were found. Furthermore, the proportion of the individual bands in the total proteins of the fraction was altered during the maturation process. This phenomenon was very marked when $0 \cdot 01 \mathrm{~N}-\mathrm{NaOH}$-extracted proteins were separated at $\mathrm{pH} 8 \cdot 6$. In this case,

(a)

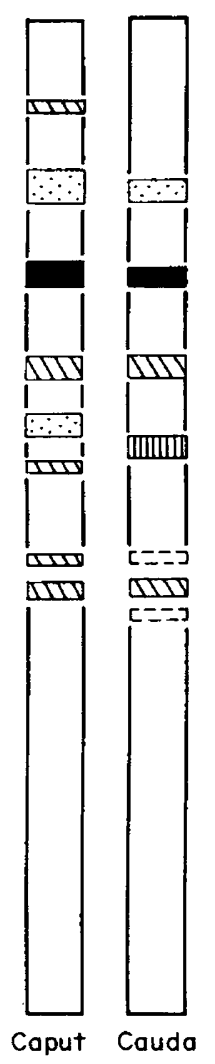

Bull 3

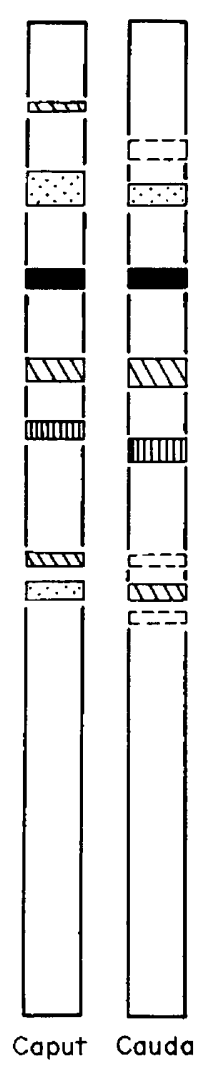

Bull 4

TEXT-FIG. 1. Electrophoretic separation (a) at $\mathrm{pH} 4.5$, and (b) at $\mathrm{pH} 8 \cdot 6$ of the proteins in the $\mathrm{F}_{1}$ fraction extracted by $0.01 \mathrm{~N}-\mathrm{NaOH}$ from spermatozoa of the caput and cauda epididymidis.

about twenty bands were identified and some of them stained to different intensity in the fractions from the caput and the cauda. At $\mathrm{pH} 4.5$, however, smaller differences were observed between caput and cauda cell extracts. In the $0.1 \mathrm{~N}-\mathrm{HCl}$ extract $\left(\mathrm{F}_{2}\right)$, typical differences between the caput and the cauda sperm cells were found at $\mathrm{pH} 4 \cdot 5$, whereas in the $\mathrm{F}_{3}$ fraction no differences were observed. In the $3 \% \mathrm{NaOH}$ extract $\left(\mathrm{F}_{4}\right)$, a small band was identified in the cauda which was absent in the sperm cells from the caput epididymidis. 


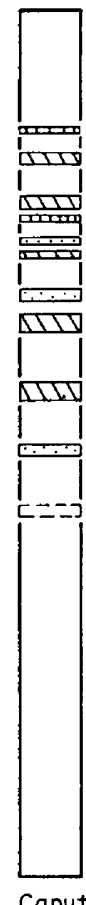

Caput

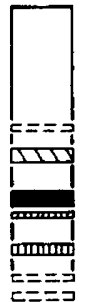

ताग

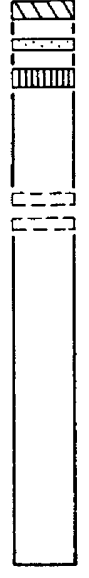

Cauda
I [

2

$3 \Delta 11$

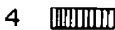

5

Groding of colour intensity

Bull 3

TexT-FIC. 2. Electrophoretic separation at $\mathrm{pH} 4.5$ of the proteins in the $\mathbf{F}_{2}$ fraction extracted by $0.1 \mathrm{~N}-\mathrm{HCl}$ from spermatozoa of the caput and cauda epididymidis.

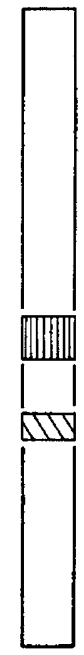

Caput
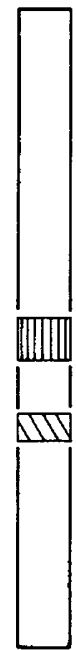

Caudo

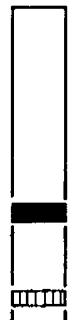

IIII)

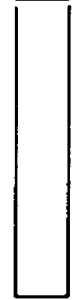

Caput

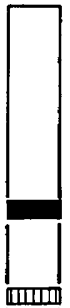

IIIIII)

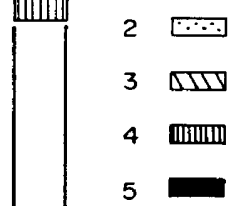

Groding of colour intensity

Bull 3

Bull 4

TexT-FIG. 3. Electrophoretic separation at $\mathrm{pH} 4.5$ of the basic proteins in the $\mathrm{F}_{3}$ fraction extracted by $0.1 \mathrm{~N}-\mathrm{HCl}$ from spermatozoa of the caput and cauda epididymidis following mercaptoethanol treatment. 


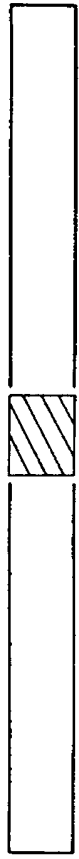

Coput

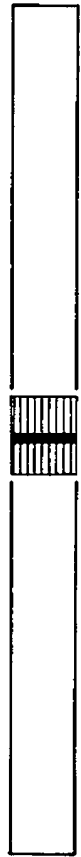

Couda
I $5--$ ]

$2 \because \because$

3 DIV

4 आII)

5

Groding of colour intensity

Bull 3

TEXT-FIG. 4. Electrophoretic separation at $\mathrm{pH} 4.5$ of the proteins in the $\mathbf{F}_{4}$ fraction extracted by $3 \% \mathrm{NaOH}$ from spermatozoa of the caput and cauda epididymidis.

\section{DISGUSSION}

The results of the present study confirm that the decrease in the dry matter content of spermatozoa, which occurs during maturation (Lavon, Volcani \& Danon, 1970), is partly attributable to a loss of proteins. This conclusion is based on the findings that the total nitrogen content decreases, whereas the DNA nitrogen remains constant when the spermatozoa migrate from the caput to cauda epididymidis. The results on DNA are in agreement with those reported by Bouters, Esnault, Salisbury \& Ortavant (1967) and Bouters \& Vandeplassche (1968). Other nitrogen compounds do not contribute to the decrease in nitrogen as their quantity is very low (Bhargava et al., 1959a). The above findings are supported also by the results of the dry matter extraction, which showed a decrease in protein content during sperm passage from the caput to cauda epididymidis. The marked decline in the protein content in the $F_{1}$ fraction is responsible for this decrease. This finding is further strengthened by the fact that the proteins of the other fractions increase slightly during this stage of maturation.

The data concerning the amino acid composition of the lyophilized dry matter of spermatozoa from the caput and cauda epididymidis, demonstrate clearly that changes in various protein groups did occur during maturation. From the dry matter extraction, it can be concluded that the differences in the amino acid percentage in relation to the dry matter are due principally to quantitative 
changes in the proteins of the various fractions. However, qualitative differences were also found. Significant changes in several amino acids were found in Fractions $F_{1}$ and $F_{2}$ and were indicated in other fractions. The marked decrease in the protein content from caput to cauda spermatozoa in the $F_{1}(0.01$ $\mathrm{N}-\mathrm{NaOH}$ extract) fraction is responsible for the decline in the percentage of the acidic and some of the neutral amino acids (such as leucine), all of which are present in high proportion in this fraction. The increase in the percentage of arginine in the total proteins is explained by the increase in the basic $F_{3}$ and $\mathbf{F}_{4}+\mathrm{F}_{5}$ fractions, although the latter was not significant. This was attributed to the high arginine content in the proteins of those fractions. A slight increase of their quantity is sufficient to produce a marked elevation in the arginine percentage. This conclusion is supported by the findings of Berry \& Mayer (1960) on the increase in the ratio between basic and acidic acids in the basic proteins during maturation. A similar reasoning seems to be acceptable for cystine, as its content in those fractions was much higher than in Fractions $\mathrm{F}_{1}$ and $\mathrm{F}_{2}$.

From the results of Fractions $F_{4}$ and $F_{4}+F_{5}$, it was obvious that the $F_{5}$ undissolved precipitate was rich in cystine and seemed to be a keratin-like protein. The presence of such a protein was postulated by Green (1940) and was indicated also by Zittle \& O'Dell (1941), Berry \& Mayer (1959) and Henricks \& Mayer (1965b). Contrary to expectations, however, the percentage of cystine in this fraction was very low $(1 \%)$. The fate of the 'residual' cystine, which was present in the $F_{4}+F_{5}$ fractions, is not yet clear.

The electrophoretic separations of the extracted proteins support the findings on the amino acid composition of the same proteins, as both qualitative and quantitative differences in the individual protein bands between caput and cauda sperm cells were observed. These differences were found in those fractions which showed a different amino acid pattern for caput and cauda cells $\left(\mathbf{F}_{1}\right.$, $\mathrm{F}_{2}$ and $\mathrm{F}_{4}$, although the last is not significant), and might reflect the slight changes in the percentage of several amino acids in those proteins.

The decrease in the colour intensity of several bands in the electrophoretic separation of caput and cauda sperm proteins can be explained by the degradation of those proteins during maturation. A decrease in the amount of total lipids and of the main lipid fractions, particularly those connected in the lipoprotein complexes, occurs during sperm maturation in the epididymis (Scott, Dawson \& Rowlands, 1963; Dawson \& Scott, 1964; Grogan et al., 1966; Pickett \& Komarek, 1967; Pickett, Komarek, Gebauer, Benson \& Gibson, 1967; Quinn \& White, 1967; Scott, Voglmayr \& Setchell, 1967; Scott \& Dawson, 1968; Lavon et al., 1970) and was assumed to be the result of their utilization as a source of energy in the absence of carbohydrates (Quinn \& White, 1967; Scott et al., 1967). It seems likely that a parallel degradation occurs in the related proteins during the maturation process.

The increase in the colour intensity of some bands and the appearance of new ones can be explained by two postulates: (a) the bands which seem to increase in proportion remain, in fact, constant in quantity, whereas the others decrease. This assumption does not explain the appearance of new bands during maturation. It is, however, possible that the new bands were present in very 
small amounts and therefore could not be detected and identified in the caput, but later increased in proportion and appeared in the cauda sperm cells. It is also possible that they appeared as a result of protein degradation. (b) The synthesis of proteins continues during cell maturation. There is some evidence in the literature on the possibility of RNA and protein synthesis by ejaculated spermatozoa (Bhargava, 1957; Bhargava, Bishop \& Work, 1959b; Abraham \& Bhargava, 1963; Iype, Abraham \& Bhargava, 1963). However, this synthesis was attributed by other investigators to bacteria contaminating the ejaculated cells and not to the spermatozoa themselves (Martin \& Brachet, 1959; Setchell, Hinks, Voglmayr \& Scott, 1967). The present study does not exclude the possibility of protein synthesis occurring during the passage of spermatozoa through the epididymis while they still possess cytoplasmic droplets.

From the results of this study, it can be concluded that the major changes in quantity, composition and electrophoretic behaviour of the sperm proteins are demonstrated in the best way in the $\mathrm{F}_{1}(0.01 \mathrm{~N}-\mathrm{NaOH}$-extracted) fraction. The site of alterations is, therefore, most probably located in the lipoprotein complexes, e.g. in the cell membrane. In addition, minor changes appear to occur in the nucleoproteins.

\section{ACKNOWLEDGMENTS}

This study has been financed in part by a grant awarded by the United States Department of Agriculture under P.L. 480. The authors are indebted to Mr D. Zismann for his technical assistance.

\section{REFERENCES}

Agraham, K. A. \& Bhargava, P. M. (1963) The uptake of radioactive amino acids by spermatozoa. Biochem. 7. 86, 308.

AlfERT, M. (1956) Chemical differentiation of nuclear proteins during spermatogenesis in the salmon. 7. biophys. biochem. Cytol. 2, 109.

BERRY, R. E. \& MAYER, D. T. (1959) The isolation of some cellular constituents of bovine spermatozoa. Expl Cell Res. 18, 398.

BerRy, R. E. \& MAYER, D. T. (1960) The histone-like basic protein of bovine spermatozoa. Expl Cell Res. 20, 116.

Bhargava, P. M. (1957) Incorporation of radioactive amino acids in the proteins of bull spermatozoa. Nature, Lond. 179, 1120.

Bhargava, P. M., Bishop, M. W. H. \& Work, T. S. (1959a) The chemical composition of bull semen with special reference to nucleic acids, free nucleotides and free amino acids. Biochem. F. 73, 242.

Bhargava, P. M., Bishop, M. W. H. \& Work, T. S. (1959b) Incorporation of $\left[{ }^{14} \mathrm{C}\right]$ amino acids into the proteins of bull spermatozoa. Biochem. F. 73, 247.

Bouters, R., Esnault, C., Salisbury, G. W. \& Ortavant, R. (1967) Discrepancies in analyses of deoxyribonucleic acid in rabbit spermatozoa, involving Feulgen staining (Feulgen-DNA) and ultraviolet light absorption (UV-DNA) measurements. F. Reprod. Fert. 17, 355.

Bouters, R. \& VANDEPLAssche, M. (1968) Vergleichende mikrospektrophotometrische Bestimmungen von Feulgen-DNS an epididymären, ampullären, ejakulierten und durch Massage gewonnenen Spermien von Bullen. Zuchthygiene, 3, 1 .

Bril-Petersen, E. \& Westenbrinik, H. G. K. (1963) A structural basic protein as a counterpart of deoxyribonucleic acid in mammalian spermatozoa. Biochim. biophys. Acta, 76, 152.

Glare, N. T. \& Stevenson, A. E. (1964) Measurement of feed intake by grazing cattle and sheep. $\mathrm{X}$. Determination of nitrogen in faeces and feeds using an auto-analyzer. N.Z. Zl agric. Res. 7, 198. 
DAvis, B. J. (1964) Disc electrophoresis. II. Method and application to human serum proteins. Ann. N.Y. Acad. Sci. 121, 404.

Dawson, R. M. G. \& ScotT, T. W. (1964) Phospholipid composition of epididymal spermatozoa prepared by density gradient centrifugation. Nature, Lond. 202, 292.

FeLIx, K. (1960) Protamines. Adv. Protein Chem. 15, 1.

Fiske, G. \& Subrarow, Y. (1925) The colorimetric determination of phosphorus. F. biol. Chem. 66, 275.

Gledhill, B. L., Gledhill, M. P., Rigler, R., JR \& Ringertz, N. R. (1966) Ghanges in deoxyribonucleoprotein during spermiogenesis in the bull. Expl Cell Res. 41, 652.

Green, N. W. (1940) The chemistry and cytology of the sperm membrane of sheep. Anat. Rec. 76, 467.

Grogan, D. E., MAYer, D. T. \& Sikes, J. D. (1966) Quantitative differences in phospholipids of ejaculated spermatozoa and spermatozoa from three levels of the epididymis of the boar. $\mathcal{f}$. Reprod. Fert. 12, 431.

Henrigks, D. M. \& MAYer, D. T. (1965a) Characterization of the basic proteins associated with DNA in mammalian spermatozoa. Proc. Soc. exp. Biol. Med. 119, 769.

Henricks, D. M. \& MAYer, D. T. (1965b) Isolation and characterization of a basic keratin-like protein from mammalian spermatozoa. Expl Cell Res. 40, 402.

Hunter, A. G. \& Hafs, H. D. (1964) Some physicochemical properties of saline-soluble proteins in bovine spermatozoa. 7. Reprod. Fert. 8, 243.

Ingles, G. J., Trevirhick, J. R., Smith, M. \& Dixon, G. H. (1966) Biosynthesis of protamine during spermatogenesis in salmonoid fish. Biochem. biophys. Res. Commun. 22, 627.

Iype, P. T., Abraham, K. A. \& Bhargava, P. M. (1963) Further evidence for a positive role of acrosome in the uptake of labelled amino acids by bovine and avian spermatozoa. F. Reprod. Fert. 5,151 .

Lavon, U., Volcani, R. \& Danon, D. (1968) Determination of dry matter percentage of ejaculated and epididymal bull spermatozoa after differential flotation. 7. Reprod. Fert. 17, 151.

Lavon, U., Volcant, R. \& Danon, D. (1970) The lipid content of bovine spermatozoa during maturation and ageing. F. Reprod. Fert. 23, 215.

Lowry, O. H., Rosebrough, N. J., FarR, A. L. \& Randall, R. J. (1951) Protein measurement with the Folin phenol reagent. F. biol. Chem. 193, 265.

ManN, T. (1964) The biochemistry of semen and of the male reproductive tract, Chap. V and VI. Methuen, London.

Martin, F. \& Brachet, J. (1959) Autoradiographic studies on the incorporation of amino acids into spermatozoa. Expl Cell Res. 17, 399.

Mayer, D. T., Madera-Orsint, F. \& BerRy, R. E. (1957) Lipoprotein complex, nucleic acids and other constituents of bovine spermatozoa. Fedn Proc. Fedn Am. Socs exp. Biol. 16, 219.

Picketr, B. W. \& Komarek, R.J. (1967) Lipid and dry weight of bovine seminal plasma and spermatozoa from first and second ejaculates. F. Dairy Sci. 50, 742.

Picketr, B. W., Komarex, R. J., Gebauer, M. R., Benson, R. W. \& Grbson, E. W. (1967) Lipid and dry weight of ejaculated, epididymal and post-castrate semen from boars. F. Anim. Sci. 26, 792.

Quins, P. J. \& Whrte, I. G. (1967) Phospholipid and cholesterol content of epididymal and ejaculated ram spermatozoa and seminal plasma in relation to cold shock. Aust. F. biol. Sci. 20, 1205.

Reisfeld, R. A., Lewis, U. J. \& Williams, D. E. (1962) Disc electrophoresis of basic proteins and peptides on polyacrylamide gels. Nature, Lond. 195, 281.

ScotT, T. W. \& Dawson, R. M. C. (1968) Metabolism of phospholipids by spermatozoa and seminal plasma. Biochem. F. 108, 457.

Scott, T. W., Dawson, R. M. C. \& Rowlands, I. W. (1963) Phospholipids interrelationships in rat epididymal tissue and spermatozoa. Biochem. 7. 87, 507.

Scott, T. W., Voglmayr, J. K. \& Setchell, B. P. (1967) Lipid composition and metabolism in testicular and ejaculated spermatozoa. Biochem. F. 102, 456.

Setchell, B. P., Hinks, N. T., Voglmayr, J. K. \& Scott, T. W. (1967) Amino acids in ram testicular fluid and semen and their metabolism by spermatozoa. Biochem. f. 107, 1061.

SNedecor, G. W. (1948) Statistical methods. Iowa State College Press, Ames, Iowa.

Summerhill, W. R. \& Olds, D. (1961) Levels of deoxyribonucleic acid in bovine spermatozoa and their relationship to fertility. F. Dairy Sci. 44, 548.

VeNDRely, R., KNOBLOCH, A. \& VENDRELY, C. (1957) An attempt of using biochemical methods for cytochemical problems; the desoxyribonucleoprotein of spermatogenetic cells of bull testis. Expl Cell Res. Suppl. 4, 279.

ZItTLE, G. A. \& O'Dell, R. A. (1941) Chemical studies of bull spermatozoa. Lipid, sulfur, phosphorus and nucleic acids of whole spermatozoa and of the parts obtained by physical means. $\mathcal{F}$. biol. Chem. 140, 899. 